\title{
United or Autonomous: Can Scotland Eventually Achieve Independence?
}

\author{
Chenyu Song ${ }^{1, a}$ \\ ${ }^{1}$ Liaoning Province Shiyan High School, Shenyang 110000, P.R. China \\ achenyus@gmx.com
}

Keywords: Scotland, independence wars, Brexit vote

\begin{abstract}
This article mainly recalls the history of the two independence wars of Scotland. The author discusses the reasons, the processes and the influences of each independence war, as well as the facts Scotland nowadays faces including the fact of losing economy independence. Although disadvantages exist, Scotland people continuously vote for their independence. Therefore, from the author's aspect of view, the outcome of Scottish independence is obvious and Scots can eventually achieve their freedom.
\end{abstract}

\section{Introduction}

For approximately a thousand years, the kingdoms of England and Scotland have on and off fought numerous wars. As a result, their common border has frequently changed and is a highly contested space. One of the most prominent examples of such warfare is the Wars of Scottish Independence (1296-1357). Despite a convenient political union in 1603 giving Scotland and England "peace and harmony" under control of King James VI of Scotland, referred to as King James I by the English at that time, the longstanding and fraught historic conflict between England and Scotland may eventually lead to the independence of Scotland. The Scots have a distinct national identity. Their national memory regularly commemorates the earlier battles against England and evokes Scots' spirit of revolting. Consequently, their nationalist discourse emphasizes that they will better off by themselves rather than as part of a greater political confederation with England.

In addition to unfavorably remembering these historical conflicts between Scotland and England, the Scottish are also dissatisfied with the loss of their economic benefits. In recent years, Scottish calls for independence have increased dramatically. Many Scottish nationalists maintain, that because of its oil and gas revenue, Scotland now contributes more to the United Kingdom than it receives. Therefore, they argue that it would be in Scotland's best economic interests to control their own economic destiny. As a consequence of these discussions, the First Scottish Referendum for independence took place in September, 2014. On that occasion, Alex Salmond, the first minister of the Scottish government stated that "the future of Scotland will be decided by the people of Scotland themselves". Yet, surprisingly, a slim majority, or 55.8\% rejected independence. However, when Salmond announced to resign, he also stated that the calls for independence will not be ceased in Scotland. As Salmond expected, Nicola Sturgeon, the new first minister of Scotland, announced to hold the Second Scottish Referendum in the end of 2018 or in 2019. As a conclusion, Scottish calls for independence are intensifying. If Scottish history teaches us one essential lesson is that the Scots are willing to fight for Independence.

\section{Two original wars of Scottish independence}

\subsection{The first war of Scottish independence}

The main reason why Scottish wants independence needs to be traced back to the first War of Scottish Independence. The war lasted from 1296 to 1328 with the beginning of the English invasion of Scotland. At first, fearing civil war between the Bruce and Balliol families, the Guardians of Scotland wrote to Edward I to arbitrate in order to avoid the civil war. However, Edward insisted that until he could be recognized as Lord Paramount of Scotland, he would not 
provide any help. Furthermore, he threatened he would send his armies to invade Scotland. Although some Scottish lords agreed to this arrangement at that time, which eventually forced them to give up their royal castles and be resigned and reappointed by Edward, the cost of this union seemed to be greater than the benefits. This led to a strong sense of dissatisfaction toward this English leader. Soon, this led to the Battle of Stirling Bridge, or the first Scottish War of Independence.

In the article The First Scottish War Of Independence, Emp. Barbarossa (pseud.) described the situation as "William Wallace would move his forces to join Andrew Moray's forces at Stirling, where the famous Battle of Stirling Bridge would take place.The Battle of Stirling Bridge took place on September 11, 1297. The Scottish forces, under Moray and Wallace, numbered around 10,000-20,000 men(though some nationalistic sources will say 40,000-60,000). The English were commanded by Earl John de Warenne the same man who, though outnumbered nearly three-to-one, had beaten the Scots in 1296 at the Battle of Dunbar. He had an army of about 60,000 men, made up of elite heavy cavalry, Welsh longbowmen, and heavy infantry."[1]. With a victory of Scottish armies and a devastating English defeat, the Scots succeeded in occupying the entire Lowlands and opened North England to the Scottish raiders, which proved to be an indispensable opportunity for the Scottish militia. According to The Battle of Stirling Bridge by Knjaz Milos, "The battle was a huge morale boost for the Scotts. After years of defeats and humiliation at the hands of English, they finally managed to strike a blow against the invaders. Although Bannockburn was a far more influential battle, it was at Stirling that the Scotts showed the world and themselves that they aren't defeated and that they still had some fight left in them. To this day, the battle of Stirling holds a special place in the hearts of Scotsmen." [2]. From such an early time, the Scots have learnt to use their own power to fight against English and their aggression. In Scottish historical memory, therefore, they have an inspiring example of how to achieve some forms of independence. The particular spirit of revolting for inequity and struggling for their own rights and freedom seems like a historical template for the current Scottish discussions and battle for greater autonomy.

However, the resistance did not cease even after the death of William Wallace. There is such a scene in a famous movie called Braveheart: When William Wallace was caught and sent to England by Edward I, the English threatened Wallace and tried force him to surrender. Yet the opposite actually happened: lying on the gallows and covering his skin with blood, Wallace struggled to shout out one word - freedom - with a kind of tremulous voice. Everyone was astonished including Edward I. Obviously, the resistance of Scotland was more resolute than Edward I thought. He assumed that the death of Wallace would demoralize the Scots and prevent future rebellions. Instead, the blood of Wallace was the seed to sprout even further resurrections. In the battle of Bannockburn in approximately 1314, against all odds and facing a bigger and better equipped English army, the Scottish troops were determined to turn their disadvantage to their advantage. What they lacked in weapons, they made up with a fighting spirit. The war lasted until 1328 and ended with the signing of the Treaty of Edinburgh-Northampton. Although the Scottish spent 100,000 pounds on this treaty, what they achieve is that England agreed that The Kingdom of Scotland be fully independent. This war seemed to come to an end after this treaty and England had not interfered Scotland for several years.

\subsection{The second war of Scottish independence}

After a temporary lull, English-Scottish hostilities resumed in the 13th and 14th century. In the Second War of Independence, the Scottish wanted to keep their freedom and protect their own territory from the English. After Robert the Bruce's death, Edward III found it could be a proper time to revenge on Scotland because the King David II was too young to rule Scotland. With the support of Edward III, Edward Balliol succeeded in the battle of Dupplin Moor and defeated the larger Scottish force. This battle was a slaughter resulting in the death of the Earl of Mar, the new Guardian, and a number of nobles. Overall more than 2000 Scots had been slain. Then in October, Sir Archibald Douglas, started to fight against the Edward III and Edward Balliol. 
Although from 1332 to 1336 the Scottish were at a disadvantage because of the strength of the English army and lack of a talented lord to lead Scottish to fight back, the Scots managed to gain a momentum from 1336 to 1340. With the distraction of Edward III, Murray and Douglas succeeded in invading strongholds of Perth and Fife in England. Until the end of March, the Scottish army had reclaimed most of Scotland north of the Forth and done serious damage to the lands of Edward Balliol. Facing such a situation, Edward III sent William Montagu to Scotland to suppress the rebellion.

Yet this action proved to be somewhat futile. According to The Scottish Wars of Independence by Ewan J. Innes, MA(Hons Scot. Hist.) FSA Scot "In David's absence, a series of regents kept up the struggle. Edward personally ravaged much of the north-east in 1336, but in 1338 the tide turned. While Black Agnes, Countess of March, held Dunbar Castle triumphantly for five months (famously wiping the battlements clean when struck by siege weapons) in this year, the big break for Scotland came when Edward claimed the French throne and took his army to Flanders. The Hundred Years War with France had begun. Scotland relations with France were strengthened during this period. The Auld Alliance was repeatedly renewed with almost unaltered terms. However, while Scotland gave much in support of the alliance she generally received little in return. A great many Scots fought in France for the French king against the English during the Hundred Years War. So highly thought of were the Scottish soldiers that Charles VII formed his 'corps d'elite' the 'Garde Ecossaise' from their ranks. In 1445, he established a regular army of fifteen companies. At the head of them was the 'Gens d'Ordonnance' the Scottish Company. In these two companies generations of Scots fought with distinction." [3]. The Scottish army used to be highly respected "they were always the last off the field - if they left at all." by French army. The Scottish never gave up in taking back their own territory. With the help of France, the Scots became more confident in succeeding to keep their independence and taking back their lands. "While not to say that Scottish victory was imminently on the horizon, the early winter and spring of 1338 were a turning point for the Scottish campaign. Murray in particular was ruthless, and while suffering his own defeats left such destruction in his wake that thousands of Scottish civilians were left without food to sustain themselves, much less to fuel Balliol's cause. However, it was his dying blow. Early in the year, Murray died of an illness, but not before he had, in the words of Michael Brown, "ended the possibility of Edward III establishing stable lordship over southern Scotland." Meanwhile, William Douglas had settled in the area of Liddesdale, from which position he harassed the allies of the English. In Spring 1339, Stewart - sole Guardian after Murray's death — brought a large force against the shrinking region under Balliol's control around Perth and Cupar. English reinforcements were held back by Scottish and French ships, and Stewart won the day in August, when his enemies surrendered." With the continuous rebellion of taking back Scottish own lands, Edward III not only needed to face the stress that fighting with France in Flanders in 1340, but also forced to care for the unstoppable rebellion of Scottish.

An official end of the Second War of Scottish Independence is The Treaty Of Berwick, signed at Berwick-upon-Tweed in 1357. David II was released and the English also demanded a ransom of 100,000 merks, a kind of silver coin used in Scotland. Although at that time war-ravaged Scotland did not have the funds to pay for these reparations, they insisted to pay for the treaty. David II also agreed to name Edward III of England as his successor, which was rejected by the Scottish Parliament because the Scots did not want others to interfere their own country. The Scots still kept their dignity that maintaining independence and freedom from the Second War of Scottish Independence.

\section{The loss of economic benefits in Scotland}

As time goes on, Scotland chose to join in the union of England as the Kingdom of Great Britain in 1703. At that juncture, they felt it was in their best economic interests to be a part of the growing and expanding British Empire. However, in recent decades some Scots are starting to question whether this arrangement is sufficiently advantageous. They consider that if they can be independent from the England, they can receive more financial benefits and develop their economy more quickly. During the World War I, there are 690,000 Scottish were sent to the frontier, which was 1.5 times than the 
English. Besides, Scotland also provides a large number of warships, food (cod) and funds. As a result, the Scottish economy went into a great depression after the World War I, and nearly one tenths of the Scottish population chose or were forced to migrate to other countries In search for a better life. At that time, England did not provide any help to its ally, which was quite disappointing, yet not surprising, to the Scottish.

Recently, especially after the Brexit vote in 2016, has given Scottish independence further momentum. "We've got a united country in Scotland which wants to be part of Europe, and in the manifesto it said if Scotland was dragged out of Europe against the will of the Scottish people, then the Scottish Parliament should have the right to hold another independence referendum." said Alex Salmond. Most Scots still want to stay in the European economic system since the EU has helped many countries to develop their economy at a faster speed. The Scottish independence Referendum happened in 2014 held by Alex Salmond. The cumulative output of oil and gas producing areas on the British continental shelf mainly in the North Sea has exceeded 40 billion barrels of oil equivalent, which has generated 160 billion pounds of oil revenue for the British government since the 1980s. If Scotland can be independent, the Scots will gain $95 \%$ oil fields and $60 \%$ natural gas from the North Sea. Alex Salmond, the leader of the Scottish Independence Referendum, used to state that an independent Scotland could float onward and upward on the strength its oil and gas resources. "Don't let it pass by this moment." said by Salmond, "We are still the underdogs in this campaign." It was to serve as a reminder that most Scots that do not be under English control any more especially when they remember the historic battles.

\section{Conclusions}

For centuries, the English and Scott's have waged war against each other. The Scots can just follow their independent predecessors to fight and struggle for their own freedom. Facing the English invasions and the contempt for Scotland, Scots succeeded in using their spirit of never giving up any opportunities to protect their own rights and territories even if the sacrifice was more than they gained. The most essential thing can be that even being union with England, once England harms Scottish benefits or their freedom, the Scots will suddenly appear on the horizon to fight against England immediately. Just like the Brexit vote, Salmond said Scots have the right to be independent because most Scottish people are not willing to leave the EU.

Furthermore, there are also many examples of other regions struggling to achieve their independence that can be helpful for Scots to study and consult, such as the Catalonia independence movement. According to David Morris "Scotland and Catalonia are brothers in arms. Independence movement leaders in the two places communicate regularly. On September 18, when Scotland voted on uncoupling from the United Kingdom, Catalans were on hand.'[4]. The Scotland independence referendum is not the initial example of struggling for freedom. Scots are not and will never be lonely in their process of achieving their independence.

When the Scottish Independence Referendum was held, many Scottish citizens raised the Scottish flag made by themselves in order to express their disagreement with using the English flag and become independent from England. Even in the Scottish Daily, the title "Don't let the sun set on our Union" also demonstrated Scottish hope of keeping away from England. Therefore, the outcome of Scottish independence is obvious and Scots can eventually achieve their freedom.

\section{References}

[1] E. Barbarossa, The First Scottish War of Independence, allempires.com, [Online]. Available: http://allempires.com/article/index.php?q=first scottish_war. [Accessed Sept. 15, 2018].

[2] K. Milos, The Battle of Stirling Bridge, foreignpolicyi.org, May 10, 2018. [Online]. Available: http:///the-battle-of-stirling-bridge/. [Accessed Sept. 23, 2018]. 
[3] E.J. Innes, The Scottish Wars of Independence, scottishhistory.com, 1995. [Online]. Available: http://www.scottishhistory.com/articles/independence/summary/wars part1 page1.html. [Accessed Aug. 15, 2018].

[4] D.Morris, Big Differences in Catalonia and Scotland on Independence, onthecommons.org, Oct. 10, 2014.[Online].

Available:http://www.onthecommons.org/magazine/big-differences-in-catalonia-and-scotland-o n-independence. [Accessed Aug. 30, 2018]. 